\title{
The Minimum Wage as Method of Alleviating Poverty: Current Practices versus Alternative Policy and Legal Resolutions
}

\author{
Yuyang $\mathrm{Li}^{1}$, Jie Zhang ${ }^{2} \&$ Xinxin Deng ${ }^{2}$ \\ ${ }^{1}$ International College, Zhengzhou University, Zhengzhou, China \\ ${ }^{2}$ School of Tourism Management, Zhengzhou University, Zhengzhou, China \\ Correspondence: Xinxin Deng, Zhengzhou University, School of Tourism Management, Zhengzhou, China. E- \\ mail: zzudengxin@163.com
}

Received: May 26, 2021 Accepted: June 23, $2021 \quad$ Online Published: June 27, 2021

doi:10.5539/jpl.v14n4p14 URL: https://doi.org/10.5539/jpl.v14n4p14

\begin{abstract}
Poverty is a social issue that impacts much of the world, including the United States. Oftentimes, proponents of the minimum wage argue that a higher minimum wage would help alleviate poverty in the country. Whether or not there will be impacts, or how significant the impact will be, is a subject of debate. The paper first analyzes arguments in support of using the minimum wage to reduce poverty in the US. Then, arguments against the current minimum wage are presented. Discussion regarding alternatives or alterations to the current minimum wage is raised at the end of the paper that would provide a more sustainable and legally sound public policy choice. This includes an analysis of the current minimum wage policies in the city of Philadelphia as example.
\end{abstract}

Keywords: minimun wage, legislative protection, public policy

\section{Introduction}

The economic recession of 2008 and its aftermath has caused economic turmoil within the U.S. Included in such turmoil are the effects on U.S. residents who are in poverty. In fact, the number of people in the U.S. who are in poverty has been increasing as of the recent years. This situation is daunting given that the U.S. Census in 2010 showed that $22 \%$ of the 18 and under age group is impoverished. ("Income, Poverty and Health Insurance Coverage in the United States: 2010 - Tables \& Figures).

Given these figures, there exists a need to re-evaluate measures that the government can take to help alleviate poverty in the U.S. One of the commonly mentioned measures to alleviate poverty is the minimum wage, which currently rests at $\$ 7.25$ per hour as the Federal Minimum Wage (Fair Labor Standards Act Advisor). The conventional argument is that this would guarantee at least a minimal amount that needs to be paid, which utilizes the government's regulatory powers to bring forth such a guarantee. However, opponents argue that the above assumes that the market for labor would not change with the minimum wage. Whereas in practice, when the price of labor goes up because of the minimum wage, demand from businesses or employers for labor may be reduced as well, leaving people jobless. This paper explores both arguments in depth, and evaluates the effectiveness of alterations to the current law. Ultimately, the measure depends on the values and priorities of policymakers.

\section{Support for the Minimum Wage}

There are many studies and economic models that support the argument that the minimum wage as it stands is helpful in reducing poverty in the U.S. From these studies, the conventional argument for implementing the current minimum wage is that given that employers would like to reduce cost, the market equilibrium for labor may be too low and exploitative of the worker. As a result, the federal minimum wage is aimed to establish a baseline of wage as to secure at least a minimum amount of pay. A study by Stevans and Sessions found that minimum wage is inversely related to poverty, and the relation is scientifically significant. This implies that as minimum wage increases, poverty rate decreases (72).

The argument in support of the minimum wage is illustrated through the following statement from Vedder and Gallaway:

"The implicit assumption of the proponents of mandated minimum wage is that the "income effect" arising from higher worker compensation among those working would be greater than the "substitution effect" arising from 
employers substituting other resources for labor as a consequence of the increased employee costs. The unemployment effects of minimum wages are either ignored or assumed to be small" (41).

One of the merits of the federal minimum wage is that it has been helpful in alleviating poverty in teenagers, as shown through a study by Addison and McKinley. According to the researchers:

"Simulations that consider the impact of minimum wages on the inequality of family incomes point to very modest effects. In a study that is notable for its attempt to accommodate accompanying changes in tax and transfer payments, Johnson and Browning (1983) found that a hypothetical 22\% increase in the minimum wage in 1976 would have had essentially no effect on the Gini coefficient for family incomes" (395).

The low correlation in previous studies may be due to an excessive pool of families, insufficient data, or flawed means of measurement. Therefore, in their research, Addison and McKinley strictly measured the effect of the minimum wage on low income families and over a longer period of time to measure stability (396).

The findings show that the average weekly earnings of teenager and junior high drop outs are small, an indication that allowing the minimum would have a larger effect on these demographic groups (Addison and McKinley 400). Furthermore, there is a "negative estimated coefficient for the minimum wage variable, implying that higher minimum wages reduce poverty" and such is especially strong for teenagers and junior high dropouts (Addison and McKinley 401). Specifically, for these two groups, a $10 \%$ increase in the minimum wage is found to reduce the poverty rate by $5 \%$ (Addison and McKinley 401 ). According to the research, not only does the minimum wage significantly reduce the poverty rate among young adults, the minimum wage may even have induced increased employment in the period of the 1990s (Addison and McKinley 407).

\section{Opposition to the Minimum Wage}

A common argument against the minimum wage is that by forcing the wage to be potentially above the market equilibrium, the demand for labor may decrease, thus causing loss of jobs. This conventional argument is illustrated through the following figure:

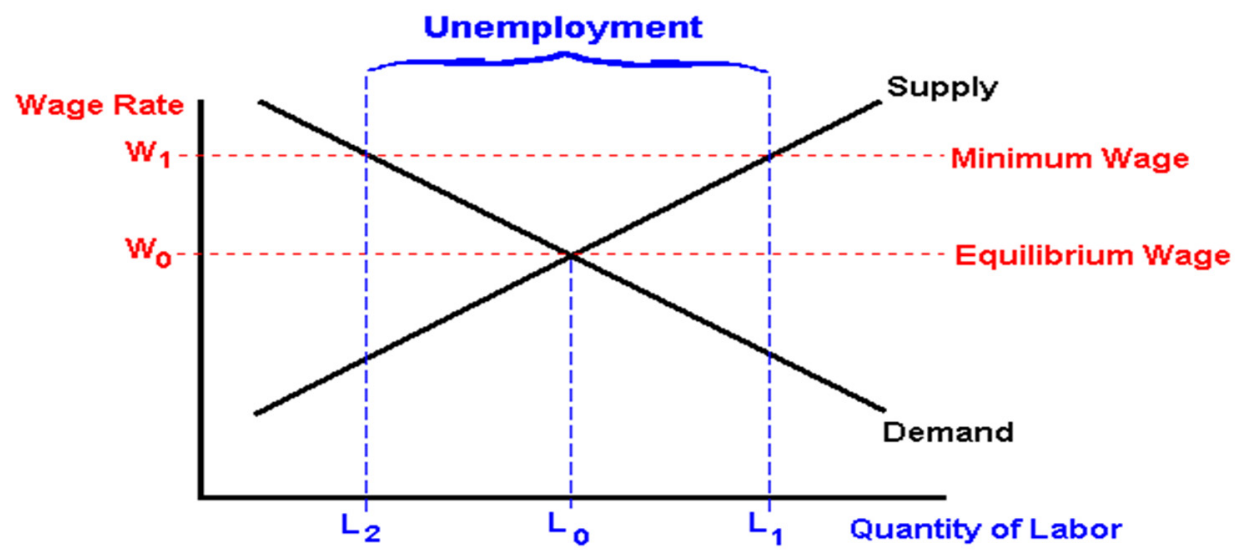

Source: “Assessing the Impact of Raising Wyoming's Minimum Wage”

In the above figure, without any regulation, the equilibrium wage exists at the intersection between the supply curve and the demand curve, which is $\mathrm{W} 0$ on this figure. However, with the minimum wage, at W1, the supply of labor (at quantity L1) clearly exceeds the demand for labor (at quantity L2). The difference of these is the unemployment gap that would arise if the minimum wage is higher than the market equilibrium. Therefore, some argue that raising the minimum brings the externality of higher unemployment.

In addition to the conventional argument, Burkhauser and Sabia found that "state and federal minimum wage increases between 2003 and 2007 had no effect on state poverty rates" (592). When the researchers simulated an increased in the minimum wage from $\$ 7.25$ to $\$ 9.50$ per hour, assuming no job losses, they found that only $11.3 \%$ of beneficiaries are from impoverished households. The simulations, assuming potential job losses, show that if such is the case then the poor will be significantly impacted with a reduction in employment opportunities (Burkhauser and Sabia 592).

Furthermore, it is estimated that given the employment elasticity of 0.6 for low income workers (aged 16-29) and 0.2 for older low income workers, about 1.3 million jobs would have been lost if a minimum wage increase were 
to be put in place. This estimated loss of jobs further confirms the argument that as the minimum wage increases, unemployment due to lower labor demand would increase as well. In fact, numerous studies show that "the leastskilled workers experience the strongest disemployment effects from minimum wage increases" (Burkhauser and Sabia 593-595).

Another reason that any increases in the minimum wage would not be effective at reducing poverty is the demographic composition of minimum earners. In the words of Burkhauser and Sabia:

"But even under the optimistic assumption of no employment or hours worked effects, the authors find that workers living in poor households received few of the benefits of past minimum wage increases because their hourly wages were already greater than the proposed state or federal minimum wages. Instead, most of the benefits went to second or third earners living in households well above the poverty line" (595).

This finding means that those who are primary earners in low income household likely have an income somewhat above the minimum wage (although not an extravagant income). Those who do benefit the most are likely young adults who utilize the minimum wage to earn supplementary income for leisure consumption.

Similarly, another research also indicate that the minimum wage is not effective at reducing poverty. In a review of Formby, Bishop and Kim's book, Leigh states that the authors have found that "poor households are indeed more likely to earn near-minimum wages, but estimate that the earnings of low-wage workers accounted for only 10-15 per cent of the disposable income of low-income families" (97). With such an assumption, Formby, Bishop and Kim argue that the disemployment effect might occur since labor elasticities vary. In fact, they make the case that labor elasticities vary by age, race, and gender. Given these variations, the researchers find that the minimum wage does not hurt the poor in general. However, it is not very effective since " $45-49$ per cent of the benefits accruing to those in the top three quintiles of the income distribution" (Leigh 97-98).

In another study, hundreds of regressions were run relating poverty rates to the minimum wage and there were generally no significant relationship between the poverty rate and the minimum wage (Vedder and Gallaway 42). Meanwhile, there may be a need to study the relationship between minimum wage and employment. According to Vedder and Gallaway, Regarding the effect on employment, the minimum wage generally does not negatively impact full time, long term workers (43). The finding casts doubts on the disemployability of part-time workers. It may imply that while full time workers are not adversely affected by increased minimum wage, the fraction of part time workers may be negatively affected.

Another argument against the minimum wage is that as it makes labor more expensive than before, employers may resort to other forms of capital, rather than human capital. Since companies originally have labor and machinery, if labor begins to cost more, companies may substitute labor with machinery, and reduce employment opportunities for the people. The magnitude of this substitution effect depends on the industry, the elasticity of demand and supply, whether or how substitutable machinery is, and the corresponding prices. But ultimately, in some industries, employment opportunities may have been hindered by the minimum wage.

\section{Recommended Alternatives}

One of the alterations is to implement the living wage, which can range from $\$ 11$ to $\$ 16$ an hour depending on the geographic region. The living wage, as its name suggests, is the amount that would allow an employee to meet living needs. In this regard, it is more realistic, situational, and less arbitrary than the minimum wage. Since the living wage adjusts for the standard of living, it is likely more effective at reducing poverty. However, since it is higher than the current minimum wage, it may be more effective at increasing unemployment as well.

In a study by Stevans and Sessions, it was found that while the minimum wage does reduce poverty, there are other policies that are more effective. More specifically, the study found that if the labor force increases by $10 \%$, poverty rate would be reduced by about $15 \%$. This means that the government should encourage workforce participation as a means to reduce poverty, as opposed to using minimum wage. Specifically, this brings to the discussion the importance of alternative policies such as the earned income tax credit as an alternative (Stevans and Sessions 7274).

\section{Case Study of Current Practices and Implications for Philadelphia}

Under the current legislation in Pennsylvania, the minimum wage is $\$ 7.25$, while cities such as Philadelphia have exemptions for the employees of contractors for the city, who are entitled to a higher minimum wage. Employees in Pennsylvania shall be paid the wage rate in accordance with the amounts listed in 43 P.S. § 333.104 (Minimum Wages, 43 P.S. $§ 333.104)$. According to the statute, if the minimum wage set forth in the Fair Labor Standards Act of 1938, 29 U.S.C. $\S 201$ et seq., is higher than that of the section, then the minimum wage under this section shall be increased in the same increment as the federal minimum wage. Therefore, currently, the minimum wage 


\section{is $\$ 7.25$ per hour.}

The current Philadelphia rate is pegged to the federal minimum wage, which has not changed since 2009 despite changes in interest rate and cost of living. This means that the current minimum wage does not fluctuate as the cost of foods and rent increases. This in turn means that $\$ 7.25$ is diminishing in value in terms of its purchasing power. For example, a minimum wage earner perhaps used to be able to purchase a fast food meal for an hour's wage. Now, with food items increasing in value, $\$ 7.25$, even pre-tax is insufficient for certain fast food meals. This is unfortunate especially because it impacts real lives - wage earners who work full time for better living conditions but may not adequately do so.

While opponents of the increase may raise objections based on increased costs, the human needs are stronger than that of pure cost concerns. A common argument against any minimum wage law is that it adds costs to the business owners, and or the cost then transfers to consumers.

Another similar economics-based argument against any minimum wage legislation is the negative effect it has on the labor market. In their study, Neumark and Wascher found that in $85 \%$ of the studies they reviewed, there existed a negative effect on employment as wages increased (Neumark). ${ }^{1}$ Further, even implementing a nationwide wage increase to $\$ 10.10$ per hour would reduce total employment by 500,000 workers, which is $0.3 \%$ of the workforce. ${ }^{2}$

The research, through seemingly scientific, cannot measure all aspects of human life, which is what is truly at stake. The increased wage, at $\$ 12$ per hour, would be a $65.5 \%$ increase in hourly wage from the current federal minimum, which certainly means increased spending power for these earners. This increase may be an additional meal, a gift for their children for the holidays, or being able to fix a household item. All of these living needs cannot be simply measured through economic charts or projections. In light of this unfortunate injustice, it makes moral and policy sense to help these earners.

The Policy Regarding Minimum Wage and Benefits to be Provided by City Contractors and Subcontractors gives a glimpse of governmental intent behind similar wage-related polices: that it is the "policy of the City of Philadelphia to ensure that its contractors and subcontractors fairly compensate their workers..." ${ }^{\prime 3}$ This shows that the city intends to fairly compensate and that the city considers "fair" to denote $150 \%$ of the federal minimum wage. Therefore, it is along the city's intentions to provide fair wage to workers, which so far is $\$ 12$ per hour. It is therefore not too far a stretch to apply this to other workers in the city who are not contractors to the city. They are also employees within the city, and are Philadelphians who work. The intent and support for the $\$ 12$ to contractors should apply to the rest of the city across the board as minimum wage.

\section{Conclusion}

Based on the above arguments for against the minimum wage, it can be seen that there exist strong support from both sides. In reality, however, which way to see the issue depends on the values of the policymakers. What the policy is depends on what policymakers believe is the better way to approach the issue. Is the priority higher employment rates, or is it to give low wage workers a guarantee of income? In addition to bilateral choice of whether to maintain or abolish the system, there are alternatives to the minimum wage that may be considered. For example, poverty may be more effectively reduced if the minimum wage were to be the living wage. However, this may occur the cost of employment. Or, the government may decide to allocate more funding and resources to the EITC program or to re-evaluate the current welfare system as alternatives to minimum wage as a measure of alleviating poverty.

Based on the foregoing analysis, it is evident that in the city of Philadelphia, in particular, the legislative intent of the labor code supports arguments for a living wage. Using a similar approach and analysis as applied to other cities may resolve the debate between labor market and wage: that the intent of the labor laws is in at for workers to be able to earn a living wage and not just the minimum wage.

\section{References}

Addison, J. T., \& McKinley, L. B. (1999). Minimum Wages and Poverty. Industrial and Labor Relations Review, 52(3), 393-409. https://doi.org/10.1177/001979399905200302

\footnotetext{
${ }^{1}$ David Neumark, The Effects of Minimum Wages on Employment, Federal Reserve Bank of San Francisco Economic Letter, http://www.frbsf.org/economic-research/publications/economic-letter/2015/december/effects-of-minimum-wage-on-employment/ (last visited Nov. 16, 2016).

2 The Effects of a Minimum Wage on Employment and Family Income, Congressional Budget Office (Feb. 18, 2014), https://www.cbo.gov/publication/44995.

${ }^{3}$ Policy Regarding Minimum Wage and Benefits to be Provided by City Contractors and Subcontractors, supra.
} 
Burkhauser, R. V., \& Joseph, J. S. (2010). Minimum wages and poverty: will a $\$ 9.50$ federal minimum wage really help the working poor? Southern Economic Journal, $76(3), \quad 592$. https://doi.org/10.4284/sej.2010.76.3.592

City of Philadelphia Sub-Contractor Minimum Wage and Benefits Ordinance Question, Proposition 1. (2014, May). Ballotpedia. Retrieved from https://ballotpedia.org/City_of_Philadelphia_Sub-

Contractor_Minimum_Wage_and_Benefits_Ordinance_Question,_Proposition_1_

Fair Labor Standards Act Advisor. (n.d.). U.S. Department of Labor. Retrieved from http://www.dol.gov/elaws/faq/esa/flsa/001.htm

Glover, T., David, B., \& Craig, H. (1999). Assessing the Impact of Raising Wyoming's Minimum Wage. Wyoming Department of Employment. Retrieved from http://doe.state.wy.us/lmi/mw/mwreport.htm

Income, Poverty and Health Insurance in the United States: 2010 - Tables \& Figures. (n.d.). U.S. Census Bureau. Retrieved from https://www.census.gov/prod/2011pubs/p60-239.pdf

Leigh, A. (2006). The Minimum Wage: Its Relation to Incomes and Poverty: MLR. Economic Record, 82(256), 97-98. https://doi.org/10.1111/j.1475-4932.2006.00298.x

Living Wage Calculator. (n.d.). MIT. Retrieved from http://livingwage.mit.edu/counties/42101

Neumark, D. (n.d.). The Effects of Minimum Wages on Employment, Federal Reserve Bank of San Francisco Economic Letter. Retrieved from http://www.frbsf.org/economic-research/publications/economicletter/2015/december/effects-of-minimum-wage-on-employment/

Policy Regarding Minimum Wage and Benefits to be Provided by City Contractors and Subcontractors. (2014). Retrieved from http://www.phila.gov/ExecutiveOrders/Executive\%20Orders/EO\%203-14.pdf

Stevans, L. K., \& David, N. S. (2001). Minimum Wage Policy and Poverty in the United States. International Review of Applied Economics, 15(1), 65-75. https://doi.org/10.1080/02692170120013358

The Effects of a Minimum Wage on Employment and Family Income. (2014). Congressional Budget Office. Retrieved from https://www.cbo.gov/publication/44995

Vedder, R., \& Lowell, G. (2002). The Minimum Wage and Poverty Among Full-Time Workers. Journal of Labor Research, 93(1), 41-49. https://doi.org/10.1080/02692170120013358

\section{Copyrights}

Copyright for this article is retained by the author(s), with first publication rights granted to the journal.

This is an open-access article distributed under the terms and conditions of the Creative Commons Attribution license (http://creativecommons.org/licenses/by/4.0/). 